\title{
Using Weather Data to Explain Herbage Yield on Three Great Plains Plant Communities
}

\author{
Alexander J. Smart, ${ }^{1}$ Barry H. Dunn, ${ }^{2}$ Patricia S. Johnson, ${ }^{3}$ \\ Lan Xu, and Roger N. Gates ${ }^{5}$
}

\begin{abstract}
Authors are ${ }^{1}$ Associate Professor, Animal and Range Sciences Department, South Dakota State University, Brookings, SD 57007; ${ }^{2}$ Executive Director and Endowed Chair of the King Ranch Institute for Ranch Management, Texas A $\mathrm{M}$ University-Kingsville, Kingsville, TX 78363; ${ }^{3}$ Professor, Animal and Range Sciences Department, South Dakota State University, Rapid City, SD 57702;

${ }^{4}$ Assistant Professor, Biology and Microbiology Department, South Dakota State University, Brookings, SD 57007; and ${ }^{5}$ Associate Professor, Animal and Range Sciences Department, South Dakota State University, Rapid City, SD 57702.
\end{abstract}

\begin{abstract}
Understanding the drivers that account for plant production allows for a better understanding of plant communities and the transitions within ecological sites and can assist managers in making informed decisions about stocking rates and timing of grazing. We compared climatic drivers of herbage production for 3 plant communities of the Clayey ecological site in southwestern South Dakota: the midgrass community dominated by western wheatgrass (Pascopyrum smithii [Rybd.] A. Love); the mixed-grass community codominated by western wheatgrass, blue grama (Bouteloua gracilis [H.B.K.] Lag. Ex Griffiths), and buffalograss (Buchloe dactyloides [Nutt.] Engelm.); and the shortgrass community dominated by blue grama and buffalograss. We used herbage yield and weather data for the period 1945-1960 collected at the South Dakota State University Range and Livestock Research Station near Cottonwood, South Dakota, to develop stepwise regression models for each plant community. Midgrass herbage production was best predicted by current-year spring (April-June) precipitation, number of calendar days until the last spring day with minimum temperature $\leq-1^{\circ} \mathrm{C}$, and previous-year spring precipitation $\left(R^{2}=0.81\right)$. Mixed-grass herbage production was best predicted by current-year spring precipitation and days until the last spring freeze $\left(R^{2}=0.69\right)$. Shortgrass herbage production was best predicted by current-year spring precipitation $\left(R^{2}=0.52\right)$. Midgrass plant communities were, overall, $650 \mathrm{~kg} \cdot \mathrm{ha}^{-1}\left(\mathrm{SE}=92 \mathrm{~kg} \cdot \mathrm{ha}^{-1}\right)$ more productive $(P<0.01)$ than mixed- or shortgrass plant communities given the same climatic inputs. Our study enables managers to make timely informed decisions regarding stocking rates and timing of grazing on this ecological site in western South Dakota.
\end{abstract}

\section{Resumen}

Entender los factores que participan en la producción vegetal permite una mejor comprensión de las comunidades vegetales y las transiciones dentro de los sitios ecológicos y puede ayudar a los manejadores de pastizales a tomar decisiones fundamentadas respecto a la carga animal y época de apacentamiento. Comparamos factores climáticos que influyen en la producción de forraje de 3 comunidades vegetales del sitio ecológico Arcilloso en el suroeste de South Dakota: la comunidad de zacates medios, dominada por "western wheatgrass" (Pascopyrum smithii [Rybd.] A. Love); la comunidad de zacates mixtos co-dominada por "western wheatgrass," "blue grama” (Bouteloua gracilis [H.B.K.] Lag. Ex Griffiths), y "buffalograss" (Buchloe dactyloides [Nutt.] Engelm.); y la comunidad de zacates cortos dominada por "blue grama" y "buffalograss." Utilizamos datos climáticos y de producción de forraje del periodo 1945-1960 colectados en la Estación Experimental de Investigación en Pastizales y Ganadería de la Universidad Estatal de South Dakota ubicada cerca de Cottonwood, South Dakota, para desarrollar modelos de regresión a pasos para cada comunidad vegetal. En la comunidad de zacates medios la mejor predicción de la producción de forraje fue obtenida con la precipitación de primavera (Abril-Junio) del año en curso, el número de días julianos hasta el último día de primavera con temperatura mínima $\leq-1^{\circ} \mathrm{C}$ y la precipitación en primavera del año previo $\left(R^{2}=0.81\right)$. En la comunidad de zacates mixtos, la mejor predicción de la producción de forraje se dio con la precipitación en primavera del año en curso y los días hasta la última helada en primavera $\left(R^{2}=0.69\right)$. En la comunidad de zacates cortos la mejor predicción se obtuvo con la precipitación en primavera del año en curso $\left(R^{2}=0.52\right)$. Bajo condiciones climáticas iguales, las comunidades de zacates medios, en general, fueron mas productivas $(P<0.01)$ que las comunidades de zacates mixtos o cortos, superandolas con 650 $\mathrm{kg} \cdot \mathrm{ha}^{-1}\left(\mathrm{SE}=92 \mathrm{~kg} \cdot \mathrm{ha}^{-1}\right)$. Nuestro estudio permite a los manejadores de pastizales tomar oportunamente decisiones fundamentadas respecto a las cargas animal y épocas de apacentamiento en este sitio ecológico del oeste de South Dakota.

Key Words: climate, ecological site, production, production drivers

\section{INTRODUCTION}

Research was funded by the South Dakota State Agricultural Experiment Station and assigned Journal Series no. 3465.

Correspondence: Alexander J. Smart, Animal and Range Sciences Dept, South Dakota State University, Box 2170, Brookings, SD 57007. Email: Alexander.smar@@sdstate.edu

Manuscript received 8 June 2005; manuscript accepted 22 October 2006.
A large number of physical factors or drivers influence herbage production on rangelands. The strength of the relationships between those drivers and herbage production is highly dependent on the scale at which those relationships are examined. 
One might expect a very generalized understanding of the relationships between drivers and herbage production at a large scale, and potentially increased prediction accuracy and precision at finer scales. At a regional level, for example, Sala et al. (1988) showed that annual net primary production (ANPP) in the Great Plains increases on a longitudinal gradient from the Rocky Mountains to the east as annual precipitation increases. They reported an $R^{2}$ of 0.90 ; however, the relationship is based on average annual precipitation and production, and thus is not appropriate for explaining production on an annual basis. Also on a regional scale, mean annual temperature has been used to explain the distribution and productivity of warm-season $\left(\mathrm{C}_{4}\right)$ and cool-season $\left(\mathrm{C}_{3}\right)$ plants along a latitudinal gradient (Teeri and Stowe 1976; Sims et al. 1978; Epstein et al. 1997). Waterholding capacity of soils, as determined by soil texture, has been related to plant productivity at both the local and regional scales (Sala et al. 1988; Epstein et al. 1997). The effect of this driver may be somewhat counterintuitive (i.e., the inverse texture hypothesis; Noy-Meir 1973), with results dependent on the amount of annual rainfall received (e.g., sandy soils have greater water available for plant growth in drier regions than clayey soils because of less evaporation).

Large-scale drivers do not provide an adequate explanation of plant productivity differences at finer scales, such as the ecological site level, where additional variables may be required to account for the higher variability in productivity (Sala et al. 1988). The suite of drivers, and/or the relationships between those drivers, that determine productivity likely change among ecological sites. Many physical characteristics (e.g., soil, slope, aspect) differ among ecological sites. Within an ecological site, however, one might expect the suite of drivers, and perhaps the relationships among them, to be more stable. Certainly the physical characteristics of each land unit having the same ecological site designation are, by definition, very similar (Society for Range Management 1998). Plant communities on those units can differ, potentially resulting in very different herbage production, even when exposed to similar rainfall and temperature regimes. Thus it is quite possible that the drivers important for herbage production and/or the relationships between drivers may differ between plant communities of the same ecological site.

Understanding the drivers of herbage production at the ecological site level is important to achieving a better understanding of the plant communities and transitions within ecological sites. It is also important because this is the level at which rangeland managers must operate and manage. An understanding of the drivers and their interrelationships can improve managers' ability to alter stocking rates and timing of grazing to sustain long-term productivity of their rangelands. Ideally, managers need tools that enable them to make longrange plans based on current or recent short-term weather patterns.

The goal of this study was to evaluate the climatic drivers of herbage production for different plant communities within an ecological site to determine the extent to which the drivers and/ or the relationships between drivers change between communities. We used historical data for the mixed-grass prairie in western South Dakota from 2 unpublished reports (Johnson et al. 1951; Lewis et al. 1956) and raw data. These data from the South Dakota State University Range and Livestock Research Station near Cottonwood, South Dakota, focused on 3 plant communities found on the Clayey ecological site. Our objective was to determine the extent to which climatic drivers of annual herbage production and the relationships between those drivers differ among these 3 distinct plant communities. Since the composition of these 3 plant communities differ in the proportion of cool- and warm-season plants, we hypothesized that cool-season-dominated communities would be more responsive to spring moisture (April-June) and warm-season dominated communities would be more responsive to growing season moisture (April-August). We also hypothesized that cool-season-dominated communities would be more responsive to previous spring moisture and late-spring freezes than warmseason-dominated communities.

\section{MATERIALS AND METHODS}

\section{Site Description}

The data were collected at the South Dakota State University Range and Livestock Research Station near Cottonwood, South Dakota (lat $43^{\circ} 94^{\prime} \mathrm{N}$, long $101^{\circ} 85^{\prime} \mathrm{W}$ ). The station is in the Northern Great Plains mixed-grass prairie, approximately 120 $\mathrm{km}$ east of Rapid City. Topography is gently sloping with long, rolling hills and relatively flat-topped ridges. Climate is continental and semiarid with hot summers and cold winters. Long-term average annual precipitation from 1909 to 2004 is $407 \mathrm{~mm}, 77 \%$ of which falls from April to September. Mean daily temperature for the study area is $8^{\circ} \mathrm{C}$ with a high of $32^{\circ} \mathrm{C}$ in July and a low of $-14^{\circ} \mathrm{C}$ in January (High Plains Regional Climate Center 2003). Soils of the experimental pastures are predominantly Kyle clay (Very fine, montmorillonitic, mesic Aridic Haplusterts) and Pierre clay (Fine, montmorillonitic, mesic Aridic Haplusterts) developed over the Pierre shale formation (USDA-SCS 1987). Predominant ecological site classification is Clayey. Vegetation is typical of mixed-grass prairie. Dominant species include the cool-season $\left(\mathrm{C}_{3}\right)$ midgrass and western wheatgrass (Pascopyrum smithii [Rydb.] A. Love) and warm-season $\left(\mathrm{C}_{4}\right)$ shortgrasses, blue grama (Bouteloua gracilis [H.B.K.] Lag. Ex Griffiths), and buffalograss (Buchloe dactyloides [Nutt.] Engelm.) (Stubbendieck et al. 1992). Longterm differential season-long stocking has contributed to the maintenance of 3 distinct plant communities (Table 1): midgrass (western wheatgrass-dominated), mixed-grass (western wheatgass/blue grama/buffalograss-codominated), and shortgrass (blue grama/buffalograss-dominated). Careful and frequent adjustment of stocking rates was used throughout the period of data collection to maintain these 3 distinct vegetation communities.

\section{Climatic Variables}

Climatic data were collected from a weather station at the research station headquarters, approximately $1 \mathrm{~km}$ from the study pastures. Variables measured include daily minimum and maximum temperatures, daily precipitation, and evaporation. These data were used to develop climatic variables for each year during the 1945-1960 period evaluated in this study. Cumulative growing degree day (GDD) index was calculated for each year for the time period 1 April-30 June using:

$$
\mathrm{GDD}=\sum\left[\left(T_{\max }+T_{\min }\right) / 2-T_{\text {base }}\right],
$$


Table 1. Nine-year (1952-1960) mean percentage species composition based on biomass ( \pm standard deviation), 16-year (1945-1960) mean annual herbage production ( \pm standard deviation), and 19-year (19421960) mean stocking rate for midgrass, mixed-grass, and shortgrass communities at the South Dakota State University Range and Livestock Research Station near Cottonwood, SD.

\begin{tabular}{|c|c|c|c|}
\hline \multirow[b]{2}{*}{ Species } & \multicolumn{3}{|c|}{ Plant community } \\
\hline & Midgrass & Mixed-grass & Shortgrass \\
\hline & ---------------- & $\%$ Composition & ------------- \\
\hline Blue grama & $14(15)$ & $22(18)$ & $17(18)$ \\
\hline Buffalograss & $22(22)$ & $45(24)$ & $63(22)$ \\
\hline Western wheatgrass & $39(24)$ & $17(13)$ & $9(11)$ \\
\hline \multirow[t]{2}{*}{ Other $^{1}$} & $15(N A)$ & $16(N A)$ & 11 (NA) \\
\hline & ---------------. & $---\mathrm{kg} \cdot \mathrm{ha}^{-1}$ & --------------' \\
\hline \multirow[t]{2}{*}{ Annual herbage production ${ }^{2}$} & 2 130a (741) & $1570 b(459)$ & $1300 \mathrm{~b}(327)$ \\
\hline & 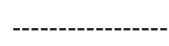 & $\mathrm{AUM} \cdot \mathrm{ha}^{-1}$ & --------------- \\
\hline Mean stocking rate ${ }^{3}$ & 0.77 & 1.01 & 1.63 \\
\hline \multicolumn{4}{|c|}{$\begin{array}{l}{ }^{1} \text { Calculated as the difference from total reported biomass; standard deviation not available. } \\
{ }^{2} \text { Means followed by a different letter are considered significantly different }(P=0.0001) \text {. } \\
\text { }{ }^{2} \text { Mean stocking rate (AUM } \cdot \mathrm{ha}^{-1} \text {, where } 1 \text { Animal Unit Month is the amount of oven-dried } \\
\text { forage required by } 1 \text { animal unit [based on } 450 \mathrm{~kg} \text { live weight] for a standardized period of } \\
30 \text { animal-unit-days). }\end{array}$} \\
\hline
\end{tabular}

where $T_{\max }, T_{\min }$, and $T_{\text {base }}$ are daily maximum temperature, daily minimum temperature, and base temperature of $5^{\circ} \mathrm{C}$, respectively.

For each year, the number of calendar days beginning 1 January until the last spring day when the daily minimum temperature was $\leq-1^{\circ} \mathrm{C}$ (days to the last spring freeze) was determined. Daily precipitation $(\mathrm{mm})$ was summed for spring (April-June), growing season (April-August), annual (JanuaryDecember), previous fall (September-November), previous spring, previous annual, winter (December-March), and previous fall + current spring (September-November + AprilJune).

\section{Herbage Yield}

This study utilized herbage yield data collected from the research station from 1945 through 1960. From 1945 to 1951, herbage yield was estimated in each pasture using 3 movable grazing exclosures (Johnson et al. 1951). At the beginning of each grazing season, grazing exclosures were relocated to different areas within the pasture to estimate the current year's herbage yield. Within each exclosure, $30.84-\mathrm{m}^{2}$ plots were hand clipped at crown level using grass shears on approximately 15 June and 15 August to estimate peak standing biomass of the cool- and warm-season vegetation. Herbage was air dried and weighed.

In 1952, 1953, and 1954, herbage production was estimated using 2 movable grazing exclosures on each of 8 different areas based on soil and topography within each pasture (Lewis et al. 1956). At the beginning of each grazing season, grazing exclosures were relocated to different areas within the pasture to estimate current year's herbage production. Within each exclosure, $30.19-\mathrm{m}^{2}$ plots were clipped in June and August. In 1952 and 1953, medium height grasses were clipped to a 2.5 $\mathrm{cm}$ stubble height, and short grasses were clipped to crown height. In 1955 all grasses were clipped just above the base of
Table 2. Single-variable correlations between climatic variables and herbage production for midgrass, mixed-grass, and shortgrass communities on a Clayey ecological site using data from 1945 to 1960 from the South Dakota State University Range and Livestock Research Station near Cottonwood, SD.

\begin{tabular}{|c|c|c|c|}
\hline & Midgrass & Mixed-grass & Shortgrass \\
\hline Climatic variables & $r P$ & $r P$ & $r P$ \\
\hline Spring $^{1}$ precipitation, $\mathrm{mm}$ & 0.380 .16 & 0.580 .02 & $0.72<0.01$ \\
\hline Growing season ${ }^{2}$ precipitation, $\mathrm{mm}$ & 0.240 .40 & 0.310 .26 & 0.550 .03 \\
\hline Annual $^{3}$ precipitation, $\mathrm{mm}$ & -0.060 .84 & 0.120 .66 & 0.240 .38 \\
\hline Previous fall ${ }^{4}$ precipitation, $\mathrm{mm}$ & -0.190 .51 & -0.200 .47 & 0.060 .82 \\
\hline Previous spring precipitation, mm & $0.69<0.01$ & 0.580 .02 & 0.110 .68 \\
\hline Previous annual precipitation, mm & 0.430 .11 & 0.120 .66 & 0.230 .40 \\
\hline Winter ${ }^{5}$ precipitation, mm & -0.220 .44 & -0.210 .46 & -0.140 .62 \\
\hline $\begin{array}{l}\text { Previous fall }+ \text { current spring } \\
\text { precipitation, } \mathrm{mm}\end{array}$ & 0.310 .26 & 0.450 .09 & $0.72<0.01$ \\
\hline Growing Degree Days (April-June) & 0.330 .22 & 0.420 .12 & 0.230 .40 \\
\hline Days until the last spring freeze ${ }^{6}$ & -0.460 .08 & -0.450 .09 & 0.030 .92 \\
\hline
\end{tabular}

${ }^{1}$ April through June.

${ }^{2}$ April through August.

${ }^{3}$ January through December.

${ }^{4}$ September through November.

${ }^{5}$ December through March.

${ }^{6}$ Number of days beginning 1 January until the last spring day with minimum temperature $\leq-1^{\circ} \mathrm{C}$

the first leaf. The clipped vegetation was dried in a forced air oven at $60^{\circ} \mathrm{C}$ for 72 hours and weighed.

From 1956 to 1960,11 to 21 movable grazing exclosures were located on each pasture to estimate herbage yield based on soil and topography. As before, exclosures were moved to new locations within each pasture at the beginning of each year. Within each exclosure, $20.19-\mathrm{m}^{2}$ plots were clipped to near ground level with grass shears in June and August to estimate peak standing biomass for cool- and warm-season vegetation. Clipped vegetation was dried in a forced air oven at $60^{\circ} \mathrm{C}$ for 72 hours and weighed.

\section{Statistical Analysis}

All variables were tested for the assumptions of normality using the NORMAL option in PROC UNIVARIATE (SAS Institute 2006). The computed $P$-value for the Shapiro-Wilk test was $P>0.15$ for all variables, verifying that they were normally distributed. The association between individual climatic variables (Table 2) and annual herbage yield from 1945 to 1960 was estimated for each plant community using correlation analysis (PROC CORR [SAS Institute 2006]). A separate herbage yield prediction equation for each plant community was also developed using multivariate regression with stepwise model selection criteria of $P<0.10$ (PROC REG [SAS Institute 2006]). This significance level was chosen to allow the procedure not to eliminate variables that may have a small predictive power but to choose a model that provides the best prediction (SAS Institute 2006). Independent climatic variables available for inclusion in these equations are listed in Table 2. Collinearity of independent variables was tested using the COLLIN option in PROC REG (SAS Institute 2006). Models with multiple variables had eigenvalues with condition indexes $(<27)$, which meant that there was no strong collinearity 

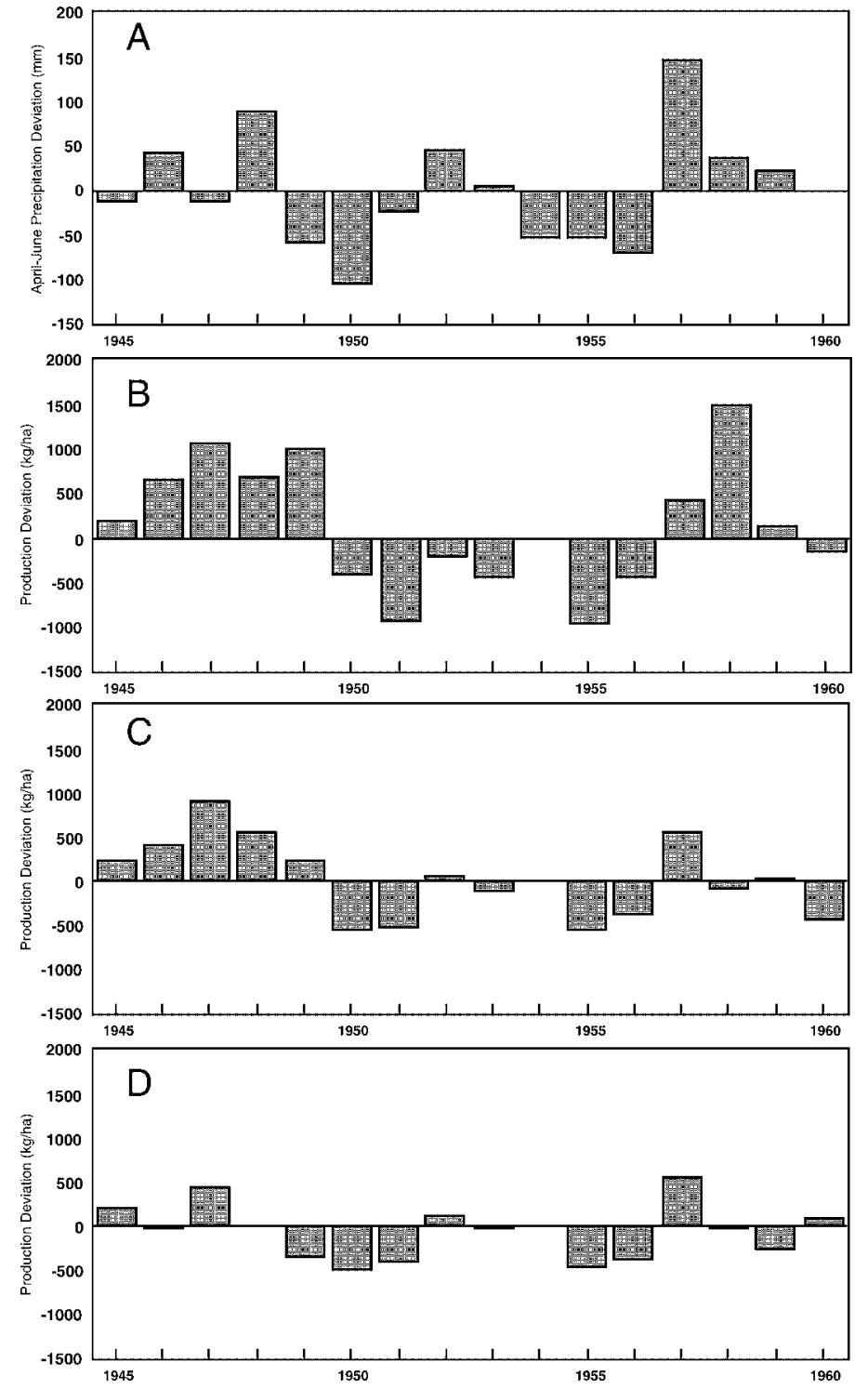

Figure 1. Deviation of annual values from the long-term (1945-1960) average for the period 1945-1960 for (A) spring (April-June) precipitation, herbage production $\left(\mathrm{kg} \cdot \mathrm{ha}^{-1}\right)$ on (B) midgrass communities, (C) mixed-grass communities, and (D) shortgrass communities at the South Dakota State University Range and Livestock Research Station near Cottonwood, SD.

between independent variables used in each model (SAS Institute 2006). Herbage production was compared between plant communities (midgrass, mixed-grass, and shortgrass) with analysis of variance using a repeated analysis computed with PROC MIXED (SAS Institute 2006) with year as replicate and a compound symmetry model that adequately accounted for error correlation among years. Homogeneity of variances of herbage production was compared between plant communities using the HOVTEST option in PROC GLM (SAS Institute 2006). The standard deviations were proportional to the means and were not homogeneous. Therefore, herbage production was $\log$ transformed according to procedures outlined by Steel and Torrie (1980). The computed $P$ value for Levene's test for homogeneity of logarithmic herbage production variance was
Table 3. Regression equations ${ }^{1}$ predicting herbage production $\left(\mathrm{kg} \cdot \mathrm{ha}^{-1}\right)$ from climatic variables for midgrass, mixed-grass, and shortgrass communities using data collected from 1945 to 1960 at the South Dakota State University Range and Livestock Research Station near Cottonwood, SD.

\begin{tabular}{llcccc}
\hline \multicolumn{1}{c}{ Plant } & & & & \\
community & Variables $^{2}$ & \multicolumn{1}{c}{ Prediction equation } & $R^{2}$ & \multicolumn{1}{c}{$P$} \\
\hline Midgrass & S, PS, & $\mathrm{Y}=2940+5.3(\mathrm{~S})+6.8(\mathrm{PS})$ & 0.81 & $<0.01$ \\
& DOY & $-24.1(\mathrm{DOY})$ & & \\
Mixed-grass & $\mathrm{S}, \mathrm{DOY}$ & $\mathrm{Y}=3053+5.2(\mathrm{~S})-20.9(\mathrm{DOY})$ & 0.69 & $<0.01$ \\
Shortgrass & $\mathrm{S}$ & $\mathrm{Y}=583.2+3.7(\mathrm{~S})$ & 0.52 & $<0.01$ \\
\hline
\end{tabular}

${ }^{1}$ Developed from stepwise regression analysis with independent variable selection criterion of $P<0.10$. Climatic variables evaluated for inclusion in each model are listed in Table 2. ${ }^{2} \mathrm{~S}=$ current year spring (April-June) precipitation $(\mathrm{mm}) ; \mathrm{PS}=$ previous year spring (AprilJune) precipitation $(\mathrm{mm})$; DOY = days until the last spring freeze (calendar day; based on 1 January $=1$ when daily minimum temperature was $\leq-1^{\circ} \mathrm{C}$ ).

$P=0.16$, which indicated that variance of logarithmic herbage production among plant communities was similar. Means were separated using the least squares PDIFF option when the $F$ test of the main effects was significant at $P<0.05$. Untransformed means and standard deviations are reported.

\section{RESULTS}

\section{Midgrass Communities}

Herbage production for the midgrass communities averaged approximately $2100 \mathrm{~kg} \cdot \mathrm{ha}^{-1}$ and was significantly greater $(P<0.05)$ than the mixed-grass or shortgrass communities (Table 1). Herbage production varied considerably over the study period (Fig. 1B), with a coefficient of variation of $35 \%$, and was not, at times, in sync with current-year spring precipitation (Figs. 1A and 1B). For example, herbage yield was $1000 \mathrm{~kg} \cdot \mathrm{ha}^{-1}$ above the long-term average in 1949 when spring precipitation was approximately $60 \mathrm{~mm}$ below average (Fig. 1A and 1B). The previous spring precipitation, however, had been above average. Similarly, in 1951, herbage yield was $950 \mathrm{~kg} \cdot \mathrm{ha}^{-1}$ below the 16 -year mean when spring precipitation was only $24 \mathrm{~mm}$ below average. Spring precipitation the previous year, however, had been $57 \%$ below average. Another example can be seen in 1957-1958 (Figs. 1A and 1B).

The only climatic variables with significant single-variable correlations $(P<0.1)$ with current-year herbage production were previous spring precipitation and the number of calendar days until the last spring freeze (Table 2). These were also the only climatic variables that yielded single-variable models with $R^{2}>0.2$. When the climatic variables were used to develop a multivariate herbage prediction model, only previous spring precipitation, current spring precipitation, and the number of calendar days until the last spring freeze were significant (Table 3 ), with a model $R^{2}=0.81$. Previous spring precipitation explained the most variation in the model with a partial $R^{2}$ of 0.48 . Current spring precipitation had a partial $R^{2}$ of 0.20 , and the number of calendar days until the last spring freeze had a partial $R^{2}$ of 0.13 . Both previous spring precipitation and current spring precipitation exerted a positive influence on herbage production (Table 3 ). The number of days until the last spring freeze, however, had a negative influence on herbage 
production. That is, the later the last spring freeze occurred, the greater the reduction in herbage production.

\section{Mixed-Grass Communities}

Herbage production for the mixed-grass community averaged approximately $1600 \mathrm{~kg} \cdot \mathrm{ha}^{-1}$, which was less than the midgrass community but not significantly greater than the shortgrass community (Table 1). Variability in herbage production over the study period was substantial (Fig. 1C), with a coefficient of variation of $29 \%$; however, it was less than the variability of production in the midgrass communities $(\mathrm{CV}=35 \%)$. Herbage production did not appear to be out of sync with current-year spring precipitation as had been seen in the midgrass community (Figs. 1A, 1B, and 1C).

Four climatic variables, spring precipitation, previous spring precipitation, previous fall + current spring precipitation, and number of days until the last spring freeze, had significant single-variable correlations $(P<0.1)$ with herbage production (Table 2). However, the multivariate herbage prediction model $\left(R^{2}=0.69\right)$ resulting from stepwise regression analysis included only spring precipitation and the number of days until the last spring freeze (Table 3). Current spring precipitation explained the most variation in the model with a partial $R^{2}$ of 0.36 . Days until the last spring freeze had a partial $R^{2}$ of 0.33 . Current spring precipitation had a positive influence on herbage production, whereas the days until the last spring freeze exerted a negative influence (Table 3), similar to their roles in the midgrass herbage production model.

\section{Shortgrass Communities}

Herbage production for the shortgrass community averaged $1300 \mathrm{~kg} \cdot \mathrm{ha}^{-1}$, which was lower than the midgrass, but similar to the mixed-grass communities (Table 1). Variability in herbage production over the study period $(\mathrm{CV}=25 \%)$ was relatively low, especially as compared with the midgrass and mixed-grass communities (Figs. 1B, 1C, and 1D). Herbage production appears to track current-year spring precipitation with no apparent lags (Figs. 1A and 1D).

Three climatic variables, spring precipitation, growing season precipitation, and previous fall + current spring precipitation, had significant single-variable correlations $(P<0.1)$ with herbage production (Table 2). However, the herbage prediction model $\left(R^{2}=0.52\right)$ resulting from stepwise regression analysis included only spring precipitation (Table 3 ). No other climatic variables added significantly to the model. As might be expected, current spring precipitation had a positive influence on herbage production (Table 3).

\section{DISCUSSION}

\section{Herbage Production}

Our results support previous studies that documented differences in herbage production among the plant community types found on the Clayey ecological site. Herbage production on the mixed-grass and midgrass plant communities is, on average, $121 \%$ and $164 \%$ (respectively) of the production of the shortgrass community, and also more variable. Infiltration rates are greater and runoff is less for western wheatgrass dominated communities than for shortgrass-dominated communities on the Clayey ecological site at the Cottonwood Station (Hanson et al. 1970; Self 1996). The result is greater soil moisture and, thus, greater production in the sites with a large western wheatgrass component. However, in spite of the highly variable precipitation in western South Dakota, the coefficient of variation in productivity, ranging from $25 \%$ to $35 \%$ for the 3 community types, was less variable than the mean (CV of $49 \%)$ of 77 sites reviewed by Le Houerou et al. (1988). A reason for lower CVs of annual production in our study maybe related to the annual variability of rainfall. Le Houerou et al. (1988) found a positive linear relationship between the CV of annual production and the $\mathrm{CV}$ of annual precipitation $(r=0.59$, $p=0.0001)$. At the Cottonwood Station during 1945-1960 the $\mathrm{CV}$ of precipitation was $21 \%$, which was less than the mean CV of $34 \%$ that Le Houerou et al. (1988) reported.

In this study, $52 \%-81 \%$ of the variation in herbage yield for native mixed-grass pastures was explained using climatic information. Studies predicting herbage yield for monocultures from climatic variables have, however, yielded higher $R^{2}$ values. For example, Currie and Peterson (1966) explained $88 \%$ of the variation in crested wheatgrass (Agropyron cristatum [L.] Gaertn.) yield from April precipitation, and Sneva and Hyder (1962) explained $80 \%-94 \%$ of the variation in forage yields from seeded ranges using crop-year precipitation. Herbage production on native rangelands has been predicted in a number of studies, but with less accuracy (Smoliak 1956; Sneva and Hyder 1962; Dahl 1963; Lauenroth and Sala 1992). Native plant communities are complex, both in composition and in response to climatic drivers. Because of greater species diversity and longer duration of herbage production it is not surprising that herbage production on these native rangelands is less predictable using a small number of climatic variables compared to seeded pastures.

\section{Climatic Drivers}

Current Spring Precipitation. In contrast to our hypothesis that cool-season communities would be more responsive to spring moisture (April-June) and warm-season-dominated communities would be more responsive to growing season moisture (April-August) our results showed that all plant communities were responsive to current spring moisture. Several other studies conducted in the Great Plains also found spring precipitation to be highly correlated with herbage production (Rauzi 1964; Hulett and Tomanek 1969; Shiflet and Dietz 1974; Smoliak 1986; Heitschmidt et al. 2005). For midgrass and mixed-grass communities, each with a substantial western wheatgrass component, spring precipitation can be expected to impact herbage production. Western wheatgrass typically initiates growth in mid-April, and peak production occurs by the end of June in the Northern Great Plains (White 1983). Warm-season shortgrasses that dominate the shortgrass plant community typically begin growth in mid-to-late May, with active growth extending into July. Spring precipitation may be stored in the upper $10 \mathrm{~cm}$ of the soil profile where the majority of shortgrass roots occur (Coffin and Lauenroth 1991), where it would be available for use by warm-season grasses (Dahl 1963) if not depleted by cool-season grasses. In years with lower than average spring precipitation, warm-season 
shortgrass production could be limited by inadequate moisture at the beginning of the warm-season growth period and by minimal or no carryover soil moisture into the warm summer months. However, in a study by Heitschmidt et al. (2005), ANPP of warm-season perennial grasses did not decline in years of spring drought when warm-season growing conditions following the spring drought in those years were favorable. It could be argued that, in communities with few or no cool-season species where rainfall is more uniformly distributed during the summer months, a driver of herbage production is more likely to include precipitation extending into summer months (see Shiflet and Dietz 1974). However, in more arid environments, with communities dominated by short, warm-season grasses, spring precipitation could be a more important determinant in herbage production than growing season precipitation.

Previous Spring Precipitation. Our results supported our hypothesis that cool-season-dominated communities would be more responsive to previous spring moisture than warmseason-dominated communities. Previous spring precipitation was a driver only in the herbage production model for the midgrass community but accounted for the highest proportion of herbage production variability in this community. The importance of spring precipitation in the previous year in explaining current-year production in the midgrass community indicates a carry-over effect on plant vigor and bud development from one year to the next. Drought in one year can reduce the number of viable buds of western wheatgrass, and therefore potential number of tillers the following growing season (Eneboe et al. 2002).

Residual soil moisture may also play a role in observed influence of previous spring precipitation on current-year production. Precipitation from a wet spring could recharge deep soil moisture. Sala et al. (1992) hypothesized that larger precipitation events tend to wet the soil to depths beyond the influence of evaporation, and the more frequently a wet day follows a wet day (small or large rainfall events) the greater the probability that water will seep deeper into the soil and remain longer. Spring rainfall at Cottonwood follows this pattern. Of the rainfall events documented during the study period, $45 \%$ occurred the day following a rainfall event and $70 \%$ occurred no more than 2 days after a previous rain. Heitschmidt et al.'s (2005) soil moisture data do not suggest that soil moisture from one spring carries over to the next. Thus, while not definitive, Heitschmidt et al.'s (2005) data do not support the idea that previous spring precipitation might impact current-year herbage production through carryover soil moisture.

While lag effects from previous year's precipitation (Hanson et al. 1982; Lauenroth and Sala 1992; Oesterheld et al. 2001) are apparent for the midgrass community, they are less so for the mixed-grass community and entirely lacking in the shortgrass communities in this study. Lauenroth and Sala (1992), however, evaluated a 52-yr data set from the shortgrass prairie in eastern Colorado and observed lags in forage production following droughts. They suggested that, while these lags were a result of a variety of interacting processes, mortality of plants and/or tillers due to drought are important in limiting the ability of a community to respond to moisture availability postdrought. Oesterheld et al. (2001) reanalyzed Lauenroth and Sala's (1992) data and found that models that included the first and second previous-year precipitation or first and second previous-year ANPP significantly increased the predictability of current-year ANPP $\left(r^{2}=0.60\right)$ compared to current annual precipitation $\left(r^{2}=0.39\right)$. Oesterheld et al. (2001) also reanalyzed Smoliak's (1986) shortgrass (cool-season-dominated) data in Alberta and found that including either previous-year precipitation or production increased the explanation of current-year production by $12 \%$. The reasons that a significant lag effect was observed for shortgrass communities in Colorado and Alberta (Oesterheld et al. 2001), but not for the shortgrass communities at Cottonwood, may be attributed to differences in precipitation and $\mathrm{N}$ mineralization. For example, a reanalysis of a 22-year data set from the tallgrass prairie in Kansas (Briggs and Knap 1995; Knapp et al. 1998) showed no apparent relationship between previous-year precipitation or production with current-year production (Oesterheld et al. 2001). It is possible that as annual precipitation increases in the Great Plains from the shortgrass prairie $(321 \mathrm{~mm}$ in eastern Colorado; Lauenroth and Sala 1992), the mixed-grass prairie (407 mm in western South Dakota; High Plains Regional Climate Center 2003) to the tallgrass prairie $(835 \mathrm{~mm}$ in northeastern Kansas; Briggs and Knapp 1995) plant communities are less sensitive to the mechanisms that reduce production during droughts or recover more quickly during wetter years. Further, in regions with higher precipitation, $\mathrm{N}$ mineralization is greater (Burke et al. 1997), and therefore more $\mathrm{N}$ would be available for growth during wet years to reduce the lag effect from a previous dry year.

Days Until the Last Spring Freeze. Our results support the hypothesis that herbage production in cool-season-dominated plant communities are influenced to a greater extent by latespring freezes than herbage production in warm-seasondominated communities. Number of calendar days until the last spring freeze influenced herbage production for communities with a large cool-season component: both midgrass and mixed-grass plant communities. Freezing temperatures during spring growth may rupture plant cell walls and damage meristematic tissue (Pearce and McDonald 1978). Fructans that provide chill tolerance decrease dramatically in spring when plants are developing stem structure (Gonzalez et al. 1990). Therefore, grass plants in a rapid growth phase would be more susceptible to freezing temperatures (Humphreys and Eagles 1988). Evidence in the literature of a freeze in late spring reducing annual herbage production is limited. However, several herbage production models have been developed that include various temperature variables and growing season lengths (Noy-Meir 1978; Armstrong et al. 1997).

The number of calendar days until the last spring freeze was not a significant variable in the herbage production model for the shortgrass community. On average, the last spring day when the minimum temperature was $\leq-1^{\circ} \mathrm{C}$ occurred 2 May and ranged from 6 April to 23 May. Warm-season grasses do not begin their rapid growth phase until June (Dickinson and Dodd 1976), well after the period of damaging spring freezing temperatures. Certainly any western wheatgrass plants within the shortgrass community would be affected by a late-spring freeze; however, these cool-season grasses make up only a minor component of the overall community. Thus the number of 
calendar days until the last spring freeze should have little or no effect on production in warm-season-dominated pastures.

\section{MANAGEMENT IMPLICATIONS}

Substantial differences may exist among plant community types within an ecological site regarding the quantity and predictability of herbage production. In the case of the Clayey ecological site in western South Dakota, communities dominated by western wheatgrass consistently produce more herbage than plant communities with greater shortgrass components. The proportion of western wheatgrass, then, is an important consideration when evaluating the costs and benefits of management options. Our models enable managers in this area to estimate reliably herbage production before the end of the growing season. Such models can assist rangeland managers in making informed decisions regarding stocking rates or other management strategies before the end of the growing season so that overstocking can be avoided. Managers need to understand that herbage production from different plant communities experiencing the same climatic inputs will not respond in a similar way. For example, in a year with a late-spring freeze, reducing stocking rates might be required to maintain the coolseason component of midgrass and mixed-grass communities, whereas shortgrass communities would be unaffected. Previous year's spring droughts will negatively affect current-year herbage production from communities dominated by western wheatgrass, whereas communities with less western wheatgrass will be affected only by current spring precipitation. Good record keeping of daily weather information (precipitation and temperature) and knowledge of plant composition of pastures will enable managers to make appropriate use of herbage prediction models to make grazing management decisions that maintain desired plant communities.

\section{LITERATURE CITED}

Armstrong, H. M., I. J. Gordon, S. A. Grant, N. J. Hutchings, J. A. Milne, and A. R. SIBBALD. 1997. A model of the grazing of hill vegetation by the sheep in the UK. I. The prediction of vegetation biomass. Journal of Applied Ecology 34: 166-185.

BrigGS, J. M., AND A. K. KNAPP. 1995. Interannual variability in primary production in tallgrass prairie: climate, soil moisture, topographic position, and fire as determinants of aboveground biomass. American Journal of Botany 82: 1024-1030.

Burke, I. C., W. K. Lauenroth, and W. J. Parton. 1997. Regional and temporal variation in net primary production and nitrogen mineralization in grasslands. Ecology 78:1330-1340.

Coffin, D. P., and W. K. Lauenroth. 1991. Effects of competition on spatial distribution of roots of blue grama. Journal of Range Management 44:68-71.

CurRie, P. O., And G. Peterson. 1966. Using growing-season precipitation to predict crested wheatgrass yields. Journal of Range Management 19:284-288.

DahL, B. E. 1963. Soil moisture as a predictive index to forage yield for the sandhills range type. Journal of Range Management 16:128-132.

Dickinson, C. E., AND J. L. Dodd. 1976. Phenological pattern in the shortgrass prairie. American Midland Naturalist 96:367-378.

Eneboe, E. J., B. F. Sowell, R. K. Heitschmidt, M. G. Karl, and M. R. Hafferkamp. 2002. Drought and grazing: IV. Blue grama and western wheatgrass. Journal of Range Management 55:73-79.
Epstein, H. E., W. K. Lauenroth, I. C. Burke, and D. P. Coffin. 1997. Productivity patterns of $\mathrm{C} 3$ and $\mathrm{C} 4$ functional types in the U.S. Great Plains. Ecology 78:722-731.

Gonzalez, B., J. Boucaud, J. Salette, and J. Langlois. 1990. Fructan and cryoprotection in ryegrass (Lolium perenne L.). New Phytologist 115:319-323.

Hanson, C. L., A. R. Kuhlman, C. J. Erickson, and J. K. Lewis. 1970. Grazing effects on runoff and vegetation on western South Dakota rangeland. Journal of Range Management 23:418-420.

Hanson, C. L., J. R. Wright, J. P. Smith, and S. Smoliak. 1982. Use of historical yield data to forecast range herbage production. Journal of Range Management 35:614-616.

Heitschmidt, R. K., K. D. Klement, and M. R. Haferkamp. 2005. Interactive effects of drought and grazing on northern Great Plains rangelands. Rangeland Ecology \& Management 58:11-19.

High Plains Regional Climate Center. 2003. Automated weather data network. University of Nebraska, Lincoln, NE. Available at: http://www.hprcc.unl.edu/ index.html. Accessed 1 June 2003.

Hulett, G. K., AND G. W. Tomanek. 1969. Forage production on a clay upland range site in western Kansas. Journal of Range Management 22:270-276.

HumphreYs, M. O., AND C. F. EAGLES. 1988. Assessment of perennial ryegrass (Lolium perenne L.) for breeding. I. Freezing tolerance. Euphytica 38:75-84.

Johnson, L. E., L. A. Albee, R. O. Smith, and A. L. Moxon. 1951. Cows, calves and grass. Brookings, SD: South Dakota Agriculture Experiment Station Bulletin 412. $39 \mathrm{p}$.

Knapp, A. K., J. M. Briggs, BlaiR, and C. L. TuRner. 1998. Patterns and controls of aboveground net primary production in tallgrass prairie. In: A. K. Knapp, J. M. Briggs, D. C. Harnett, and S. L. Collins [EDS.] Grassland dynamics: long-term ecological research in tallgrass prairie. New York, NY: Oxford University Press. p 193-221.

Lauenroth, W. K., and O. E. Sala. 1992. Long-term forage production of North American shortgrass steppe. Ecological Applications 2:397-403.

Le Houerou, H. N., R. L. Bingham, and W. Skerbek. 1988. Relationship between the variability of primary production and the variability of annual precipitation in world arid lands. Journal of Arid Environments 15:1-18.

Lewis, J. K., G. M. Van Dyne, L. R. Albee, and F. W. Whetzal. 1956. Intensity of grazing: its effect on livestock and forage production. Brookings, SD: South Dakota Agriculture Experiment Station Bulletin 459. 44 p.

Noy-MeIR, I. 1973. Desert ecosystems: environment and producers. Annual Review of Ecology and Systematics 4:23-51.

Noy-MelR, I. 1978. Grazing and production in seasonal pastures: analysis of a simple model. Journal of Applied Ecology 15:809-835.

Oesterheld, M., J. Loreti, M. Semmartin, and O. E. Sala. 2001. Inter-annual variation in primary production of a semi-arid grassland related to previous-year production. Journal of Vegetation Science 12:137-142.

Pearce, R. S., and I. McDonald. 1978. The independent assessment of frost hardiness of excised laminae, excised roots and trimmed tillers of tall fescue (Festuca arundinacea). Journal of Applied Ecology 15:885-895.

Rauzl, F. 1964. Late-spring herbage production on short-grass rangeland. Journal of Range Management 17:210-212.

Sala, O. E., W. K. Lauenroth, and W. J. Parton. 1992. Long-term soil water dynamics in the shortgrass steppe. Ecology 73:1175-1181.

Sala, 0. E., W. J. Parton, L. A. Joyce, and W. K. Lauenroth. 1988. Primary production of the central grassland region of the United States. Ecology 69:40-45.

SAS InStitute Inc. 2006. SAS OnlineDoc 9.1.3. Cary, NC: SAS Institute Inc. Available at: http://support.sas.com/onlinedoc/913/docMainpage.jsp. Accessed 1 October 2006.

Self, R. A., IV. 1996. Infiltration, runoff, and erosion characteristics of soils with various vegetation factors [thesis]. Brookings, SD: South Dakota State University. $148 \mathrm{p}$.

Shiflet, T. N., AND H. E. Dietz. 1974. Relationship between precipitation and annual rangeland herbage production in southeastern Kansas. Journal of Range Management 27:272-276.

Sims, P. L., J. S. Singh, and W. K. LauenRoth. 1978. The structure and function of 
ten western North American grasslands: I. Abiotic and vegetational characteristics. Journal of Ecology 66:251-285.

SмоцIAK, S. 1956. Influence of climatic conditions of forage production of shortgrass rangeland. Journal of Range Management 9:89-91.

SмоцIAK, S. 1986. Influence of climatic conditions on production of StipaBouteloua prairie over a 50-year period. Journal of Range Management 39:100-103.

Sneva, F. A., AND D. N. Hyder. 1962. Estimating herbage production on semiarid ranges in the intermountain region. Journal of Range Management 15: 88-93.

Society for Range Management. 1998. Glossary of Terms in Range Management. 4th ed. Glossary Update Task Group (ED.). Denver, CO: Edison Press. 32 p.
Steel, R. G. D., and J. H. Torrie. 1980. Principles and procedures of statistics: a biometrical approach. 2nd ed. New York, NY: McGraw-Hill. 633 p.

Stubbendieck, J., S. L. Hatch, And C. H. Butterfield. 1992. North American range plants. 4th ed. Lincoln, NE: University of Nebraska Press. 493 p.

Teeri, J. A., and L. G. Stowe. 1976. Climatic patterns and the distribution of $\mathrm{C}_{4}$ grasses in North America. Oecologia 23:1-12.

USDA-SCS. 1987. Jackson County Soil Survey. Washington, DC: Government Printing Office. $216 \mathrm{p}$.

WHITE, L. M. 1983. Seasonal changes in yield, digestibility, and crude protein of vegetative and floral tillers of two grasses. Journal of Range Management 36:402-405. 